\title{
Ecosystem services between integration and economics imperialism
}

\author{
$\underline{\text { Henrik Thorén }}^{1,2}$ and Sanna Stålhammar $^{1}$
}

\begin{abstract}
Here, we explore the interdisciplinary merits of the ecosystem services concept by recruiting the notion of economics imperialism. We identify four different ways in which interdisciplinary concepts can fail as interdisciplinary concepts, three of which are associated with imperialism. First, interdisciplinary concepts can fail to be integrative, typically by being overtly flexible or vague. The remaining three ways, which typically mark imperialist infringements, are: failure to achieve ontological unification, failure to maintain or accommodate a plurality of accounts when it is suitable, and the obfuscation of social or ethical values. We analyze some of the critiques that have been raised with respect to the ecosystem services concept as a case of economics imperialism. We conclude by discussing the scope and limits of the concept more broadly and what those mean for an interdisciplinary ecosystem services science going forward.
\end{abstract}

Key Words: ecosystem services; integration; interdisciplinarity; scientific imperialism

\section{INTRODUCTION}

Since the 1990s, the notion of ecosystem services (ES) has come to inhabit a central position in scientific and policy discussions about how to understand human-nature relationships. The ES framework promises to harness knowledge from both natural and social sciences, in particular, ecology and economics, to aid decision makers who are seeking to balance development and conservation aims (Burkhard et al. 2010, Braat and De Groot 2012). However, the concept is controversial, and its implementation has been marred by methodological problems. For example, the role that economics is, and should be, playing is a persistent point of contention, with conventional economic approaches having been criticized for being at odds with the many different ways in which ecologists understand complex ecosystems (Norgaard 2010). Some people have even questioned the use of monetary valuation altogether (e.g., Lele et al. 2013). Thus, there appear to be issues with respect to how the ES framework organizes the inter- and transdisciplinary work on ecosystem valuation.

Here, we investigate the interdisciplinary role and credentials of the ES concept, with a particular eye toward how the role of economics is perceived by critics of current uses of the concept. We draw on recent literature on interdisciplinarity and scientific imperialism to outline four ways in which interdisciplinarity tends to, or can, fail. We argue that all four ways appear to be represented in the critique of ES. Finally, we attempt to tease out some normative conclusions from this argument: What can be done, and how should the concept be saved?

Although a case could be made that ecology and economics, in one way or another, have been the most important disciplines so far (Braat and de Groot 2012, Chaudary et al. 2015), many of the issues that have been raised with respect to the ES framework implicate the broader social sciences. ${ }^{[1]}$ In what follows, we will examine the relationship between economics and ecology, how it is structured by the ES framework, and how this structure relates to social sciences more broadly.

We first need to make some general remarks about, and indicate some caveats to, our approach. Our aim here is to analyze the scientific discussion about ES as an instance of economic imperialism. Economic imperialism, at a first approximation, involves some form of unjustified influence of the discipline of economics on other disciplines. This contribution will be primarily qualitative; we have performed no rigorous quantitative analysis of the literature. Instead of assessing the magnitude of the influence of economics, we engage in the more limited task of mapping out the existence of different forms of imperialist influences. Moreover, the study is carried out in a broadly empirically informed philosophical tradition and is not a systematic review of papers. The aim, rather, is to provide a basis for a discussion about the scope and limits of the ES concept, in principle, and the way in which the concept promotes or constrains interdisciplinary interactions.

\section{ECOSYSTEM SERVICES BETWEEN ECOLOGY AND ECONOMICS}

The ideas underpinning the ES concept can be traced back as far as one likes to go. Mooney and Erlich (1997) begin with George Perkins Marsh's 1864 book Man and Nature. Other authors have looked to antiquity (Daily 1997, Fisher et al. 2009). The ES term is more recent than both of these examples, and the discussion began to take a form recognizable for a modern reader sometime in the late 1970s and early 1980s (Lele et al. 2013). Early contributions tended to focus on how certain life-preserving services that ecosystems provide cannot be substituted (e.g., Erlich and Erlich 1981, Erlich and Mooney 1983). Soon, however, the notion was expanded to embrace more or less all indirect benefits that functioning ecosystems may afford such as soil conservation, water purification, etc. (e.g., Westman 1977).

During the 1990s, (ecological) economics approaches to ES became more prominent, and valuation became a central aim. As Norgaard (2010:1219) notes, the work was guided by the belief that the best way to get through to decision makers and communicate the urgency and importance of ecosystem degradation was to frame matters in strict economic terms, "however revolting for those who intrinsically value nature." Daily's (1997) Nature's Services, and the widely influential and controversial publication by Costanza et al. (1997) that provided an approximation of the dollar value of the ecosphere in its entirety, were pivotal in this development. 
For an array of reasons (see Norgaard 2010), the metaphor solidified and became the locus for considerable work valuating the benefits provided by ecosystems to aid decision making directly. The Millennium Ecosystem Assessment crafted and popularized a specific ES framework, and a definition was proposed that has since gained considerable traction; in the report, ES are understood as "the functions and products of ecosystems that benefit humans, or yield welfare to society" (Millennium Ecosystem Assessment 2005).

Since then, the ES concept and related scientific efforts have diversified to include a broad array of social sciences (Braat 2018), and the science-policy interface has shifted the focus away from monetary valuation to make room for "plural values" (Díaz et al. 2015, 2018). However, it is unclear to what extent this apparent shift involves a substantive change in perspective and a departure from a conventional economics framework, and the challenges associated with such a framework.

\section{INTERDISCIPLINARITY AND SCIENTIFIC IMPERIALISM}

The field, roughly delimited by what now might be called ES science, is broadly perceived to be interdisciplinary. McDonough et al. (2017:83) express a common sentiment when they claim, "The fundamental thought behind ES is that the topic inherently combines the natural and social science." The concept of ES is interdisciplinary, connecting issues pertaining to human needs, wants, rights, and preferences to functioning and dynamics of ecosystems. Indeed, the interdisciplinary credentials of this notion have been the subject of previous discussions (Norton and Noonan 2007, Reyers et al. 2010, Lele et al. 2013).

We shall approach this issue deploying the idea of scientific imperialism. At a first approximation, scientific imperialism, as we employ the concept here, concerns transgressions between disciplines, particularly transgressions that are perceived to be epistemically or scientifically detrimental. There is some debate about whether the concept should be understood in normative terms (as something bad) or if a normatively neutral version of the concept is more appropriate. Most philosophers have opted for the latter (e.g., Mäki 2009, Rolin 2015, Fumagalli 2018); nonetheless, the discussion of imperialism squarely concerns the limits and risks of interdisciplinarity. We will return to this idea later.

A discipline is a complex entity in the sense that disciplines have many different components or dimensions. For example, Bechtel (1986) notes that disciplines can be associated with some social and institutional structure, a history, a domain of inquiry, and a set of cognitive tools and activities. Kuhn (1970:182ff) modeled disciplines on what he calls disciplinary matrices that he thought of as having a certain number of members, a set of paradigmatic problems and solutions (exemplars), values, models, and symbolic generalizations. For the present purposes, we focus on what Bechtel (1986) calls the cognitive tools. These tools include the theories, methods, models, and concepts of a discipline.

Broadly speaking, interdisciplinarity can involve any interaction among two or more disciplines along any number of different dimensions. Here, however, we focus on interactions that pertain to the aforementioned cognitive tools. Interdisciplinarity is widely associated with integration (O'Rourke et al. 2016) and has often been differentiated from "lower forms" of cross-disciplinary interaction such as multidisciplinarity on this basis (e.g., Apostel et al. 1972, Klein 1990, 2012, Bammer 2013). Integration is a concept that is difficult to analyze and has been used in more than one sense in the literature (O'Rourke et al. 2016). Integration is not one thing but many. It is common to distinguish between reductive integration, in which one theory is subsumed under another through a reductive relationship, and connective integration, which relates theories or bodies of knowledge to one another nonreductively (Cat 2017).

One way of thinking of integration in more concrete terms is in the form of interfield theories (Darden and Maull 1977, Maull 1977, Darden 1991), which are theories that connect the ontologies of two scientific fields in some way. An illustrative example is the formulation of the Boveri-Sutton chromosome theory of Mendelian heredity formulated in 1903 and 1904 by Theodore Boveri and Walter Sutton, which connected the field of classical or Mendelian genetics with cytology (Darden and Maull 1977, Maull 1977, Darden 1991). The theory stated that the gene, what geneticists at the time called the factor, was located in or on the "darkly staining bodies" that cytologists had been observing within cells (Darden 1991). This interfield theory turned out to be enormously productive in the exchange between cytology and genetics. The theory answered an important question within Mendelian genetics by providing the location of an entity that was stipulated to exist within the field. The theory also generated new predictions and problems that could be further pursued within the respective fields. For instance, the fact that genes have specific locations relative to one another meant that assortment is not perfectly random, i.e., genes closer to one another are more likely to be inherited together. This concept explained small statistical deviations with respect to certain pairs of traits. For our purposes, interfield theories organize the division of labor between disciplines and allow for what has been called problem feeding, i.e., the exchange of problems between disciplines and fields (Thorén and Persson 2013, Thorén 2015).

Finally, it should be noted that many people who have taken an interest in interdisciplinary concepts have emphasized, in one way or another, the flexibility of these concepts. Maull (1977) proposes that scientific fields can be connected by sharing terms that are continually revised by all participants, and where members of different disciplines may, at least initially, hold different versions of the concept (Thorén and Persson 2013). The influential idea of boundary objects (Star and Griesemer 1989:393) also relies on objects (or concepts) that are flexible enough to fit the different needs of collaborators while being rigid enough "to maintain [...] identity across sites." In other words, integration does not necessarily preclude differences among the involved disciplines, even with respect to the interpretation of shared concepts. The precise degree of flexibility and rigidity that concepts need to have to serve their purpose presumably can vary from one context to another.

\section{Scientific imperialism and interdisciplinary failures}

One way in which attempts at interdisciplinarity can fail is by never achieving integration. This can happen in more than one way, depending on one's idea of integration, and a failure to achieve integration need not be a scientific failure (e.g., if integration is not suitable for the context). Thus, one problem is 
in failing to achieve integration where integration is suitable, whereas another is in forcing integration where integration is not suitable (Persson et al. 2018). The latter problem conforms readily to scientific imperialism. However, scientific imperialism occurs in several forms, and there are many relevant aspects to it, both epistemological and moral.

Disciplines are typically construed as multidimensional entities with many components; theories, methods, models, and concepts are important, but so are social and institutional factors, values, practices, and preferences (Bechtel 1986). Scientific imperialism can operate on any number of these dimensions, yielding different forms of imperialism. Mäki $(2009,2013)$ differentiates between three basic forms of imperialism: that of scope, style, and standing. Imperialism of scope is explanatory and involves attempts to explain facts belonging to the domain of one discipline by deploying the explanatory resources of another. Imperialism of style concerns the "styles and strategies of research," and imperialism of standing pertains to "academic and non-academic prestige, power, and resources" (Mäki 2013:334). Although analytically distinguishable, the three forms often occur in concert.

Mäki (2013), who adopts a normatively neutral conception of imperialism in which its epistemological and moral justifications depend on particular aspects of the situation, suggests four constraints on imperialism. These constraints are: an ontological constraint requiring unification to be ontological rather than derivational, an epistemological constraint requiring of the imperializer to consider carefully and make explicit the uncertainties associated with boundary transgressing science, an axiological constraint calling on observance to social and ethical values more broadly, and finally, an institutional constraint such that scientists must "proceed under the guidance of the rules and regulations of appropriately virtuous scientific practice" (Mäki 2013:337). We highlight issues pertaining mainly to the first three of Mäki's constraints.

First, many philosophers that have taken an interest in scientific imperialism have identified the phenomenon with some form of unification (Mäki 2009, 2013). In this account, the imperialist is subsuming facts belonging to the domain of different disciplines under a single explanatory framework. Controversial examples include explaining social and behavioral facts by using evolutionary theory (see Dupré 1996, 2001). Such infringements typically rely on the assumption that phenomena belonging to these different domains are, in some respect, similar or even of the same sort. Mäki's (2013) aforementioned ontological constraint requires that this kind of infringement be carried out on the basis of real similarities. "The pursuit of unification in its ontological mode is a legitimate process of discovery of the extent to which there is unity in the world itself: the extent to which parts of the world are made of similar components, governed by similar laws, or generated by similar causal mechanisms, and so on," (Mäki 2013:336). Derivational unification, which Mäki considers to be too weak a basis for imperialist infringements, constitutes the "deriving of large classes of explanandum sentences from a parsimonious set of theoretical sentences or inferential patterns" (Mäki 2009:13). ${ }^{[2]}$ The problem with imperialism in this case is the lack of an ontological basis upon which attempts at unification should be based.
Another aspect of imperialism relates to pluralism rather than unification. Imperialism is wrong because it involves the unwarranted or premature exclusion of alternatives. John Dupré (1996:377) writes:

\section{However, typically imperialists do not merely establish embassies in foreign countries and offer advice to indigenous populations. And similarly, economic imperialists do not merely export a few tentative hypotheses into the field they invade, but introduce an entire methodology and one, I suggest, that is in many cases almost entirely inappropriate.}

Midgley (1984:159) made comments along these lines in her critique of sociobiology, making note of the "somewhat wild offers made [by sociobiologists] to take over the social sciences." The problem is not necessarily that the propositions offered are entirely misguided; the main issue is that they suppress viable alternatives for one reason or another. Mäki incorporates this idea in his epistemological constraint (2013), but whereas Mäki's motivations are epistemological and rely on uncertainty, Dupré (1996) is more appropriately understood to defend a more radical form of pluralism.

There are two points to be made. First, although unification and pluralism appear to point in different directions, there need be no conflict between achieving ontological unification and avoiding the suppression of viable alternatives. Important similarities between domains can be discovered without necessarily displacing complementary explanations. Second, unification and pluralism need not be understood as universal aims. Indeed, many pluralists have argued that the question is contingent on the particular situation (Kellert et al. 2006).

Another concern that often has been raised with respect to presumptive instances of scientific imperialism in general, and economics imperialism in particular, involves social or ethical values. In her critique of sociobiology, Midgley (1984:107) not only raises the issue of epistemological pluralism, but also points out how sociobiological theorizing tends to "devalue the valuable and conceal the important" in a much broader sense. Clarke and Walsh (2009) have something similar in mind when they write, "Scientific imperialism causes us to fail to appreciate the irreducibly pluralistic nature of human values," (Clark and Walsh 2009:203). Mäki (2013) captures these concerns in his axiological constraint.

Here, the target of the imperialist infringement is not only another discipline. The values at stake are typically thought to be grounded in broader social or ethical values. The sociobiologist, in proposing evolutionary explanations of, e.g., rape, appears to be taking an abhorrent social phenomenon and stripping it of its moral and ethical dimension. This is problematic, both from a societal perspective (rape is a social problem) and from a sociological perspective, because it is precisely the moral and ethical dimensions of this phenomenon that makes it important.

In summary, we have highlighted three aspects of imperialism: the failure to achieve unification (or integration), the failure to observe epistemological pluralism (when pluralism is appropriate), and the failure to account adequately for the appropriate values. These are not mutually exclusive failings. Often, aspects of each are present simultaneously in cases of imperialism. 


\section{ECOSYSTEM SERVICES AS AN INTERDISCIPLINARY CONCEPT}

We now return to the ES concept and its interdisciplinary credentials. We first note an important initial observation: ontological and axiological concerns that have been kept analytically separate thus far tend to collapse in the discussion about ES. The reason is because values play such a prominent role in the discussion because valuation is a central aim for ES science. Thus, some of the central ontological issues revolve precisely around the ontology of the values involved.

\section{Integration and unification}

We begin by examining how integrative the ES concept is perceived to be. It is important to note that ideas diverge regarding to what extent ES should be a concept that fosters interdisciplinary relations explicitly. To recap briefly, we are looking for two different concerns. One concern is that integration never occurs in the first place, perhaps because the boundary concept is not rigid enough. The second concern, which we have associated with imperialism, is that the connection implied by the concept is not sufficiently substantial.

We start with the first charge that integration never occurs. There are some indications that the ES field is too disaggregated. Abson et al. (2014) found a small proportion of the ES publications to be interdisciplinary, with the majority within either ecology or economics. They note, "Different ecosystem services research foci have not yet been integrated into a shared understanding or operationalization of the concept," (Abson et al. 2014:35). Different research clusters remain detached from one another. On the other hand, they argue, the clusters that have abandoned traditional disciplinary confinements and assumed a more interdisciplinary problem-oriented and systems-based approach have been more successful.

Looking at publications quantitatively, however, the picture is mixed. Chaudhary et al. (2015) trace the development of ES across academic disciplines and find that the most cited papers were from the interdisciplinary field of ecological economics, closely followed by ecology or biodiversity. McDonough et al.'s (2017) systematic literature review covering publications from 2005 and 2016 shows that environmental sciences $(34 \%)$ and agricultural and biological sciences $(27 \%)$ account for a majority of publications. Social sciences $(10 \%)$, and in particular economics (3\%), publications composed a small part of the ES literature (McDounough et al. 2017). McDounough et al. (2017) acknowledge that the categorization by subject is, by definition, not capable of accounting for actual interdisciplinary ES publications. Although interesting, studies such as the aforementioned, on their own, do not give an indication of the influence of economics on ES discussions in disciplines that are not economics, but rather show that the ES concept has received comparatively little interest in economics.

At the level of individual studies, it is clear that using ES on its own requires only minimal integration. McDonough et al. (2017) note how studies in individual research disciplines reframe ES definitions and terminology to fit within the respective disciplines in such a way as to complicate the advancement and transfer of knowledge between disciplines. The flexibility of the concept thus allows disciplines to employ the ES terminology and methodology but operate within their own disciplinary framework. It is clear that a commitment to ES does not necessitate any deeper form of interdisciplinarity. For example, Baumgardner et al. (2012) studied the role of a peri-urban forest on air quality improvement in the Mexico City megalopolis, and no attempt at valuation was made. Similarly, Donovan and Butry (2011) estimated the effect of urban trees on the rental price of single-family homes in Portland, Oregon, USA, using the valuation method of hedonic pricing whereby the only ecological component of the study was the proximity of trees to rental homes. The theoretical foundation of ES thus seems to offer a lot of room within which studies can be characterized as ES research without integrating ecology or economics and without being interdisciplinary in general. The question is: Is there too much room?

Some seem to suggest that the answer to this question is "yes." "Vagueness" is a common critique of the ES concept in general (see Schröter et al. 2014), along with complaints that central concepts are ambiguously defined and systems of categorization and classification remain somewhat inconsistent (Nahlik et al. 2012). However, the vagueness (or flexibility) of the concept is often also put forward as a strength. It has been suggested that definitions have been left intentionally vague, as was the case with the Millennium Ecosystem Assessment (2005), to spur creativity. Continuous improvement and revision, it is pointed out, is a characteristic of the developmental phase of the new field (Schröter et al. 2014). A flexible concept is more inclusive and better suited for transdisciplinary contexts (Schröter et al. 2014).

However, interpretative flexibility is not sufficient for something to be a boundary object. Boundary objects also need a "material/ organizational structure" that can meet the information needs of participants (Star 2010:602). McDonough et al. (2017) found that definitions, classification systems, and fundamental concepts are repeatedly reevaluated and revised in ways that create confusing research environments and impede implementation of the ES framework into concrete policy and management. This can be taken to suggest that the ES concept is in want as a boundary object.

A case could be made that, despite considerable efforts to make the ES concept clearer, ambiguities remain. The influential ES cascade is a conceptual model of the relationship through a number of intermediary steps between ecological structures and human values (Fig. 1; Haines-Young and Potschin 2010). Although an explicitly stated motivation for developing the model in the first place was to reduce the ambiguity of central terms (Potschin-Young et al. 2018), the model introduces many further difficulties. Costanza et al. (2017:5), for instance, suggest that the model is "at the same time an oversimplification of a complex reality and an unnecessary complication of what is essentially a very straightforward definition." For example, the cascade relies on a range of further concepts, i.e., structures, functions, services, benefits, values, capabilities, capacities, and processes, all of which are often surprisingly difficult to distinguish from one another (e.g., Potschin-Young et al. 2018).

The idea of functions in the ES cascade has been identified as especially problematic. The concept of function is often understood to have a direction, i.e., a function is a function for something, and thus has sometimes been conflated with services: ecosystem functions directed at humans. At other times, function 
Fig. 1. The ecosystem services cascade. Adapted from Haines-Young and Potschin (2010).

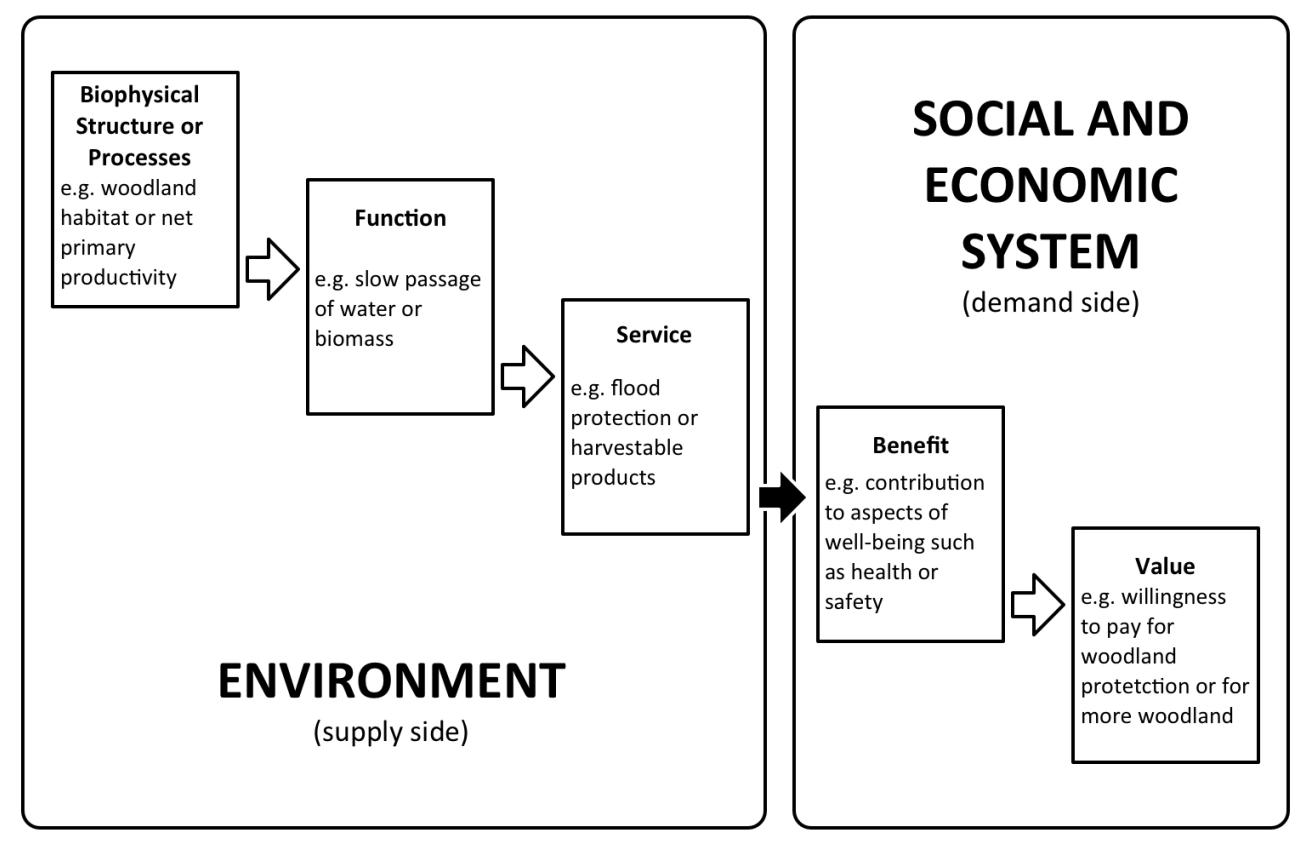

has been thought of as synonymous with ecosystem processes (Millennium Ecosystem Assessment 2005; see Jax [2016:42] for different uses of the concept in ecology). The ambivalence of these categories lead to problems when one attempts to value separate services economically. Lele et al. (2013:347) exemplify:

There is a persistent tendency in the ES literature to treat processes internal to ecosystems synonymously with ecosystem 'functions' and ecosystem 'services'. This is clearly problematic, because it leads to either double counting or the counting of and comparison between variables at different levels. For instance, nutrient cycling is not a service; it is only a process that contributes to (say) timber production service. Valuing nutrient cycling in addition to timber would then lead to double counting (as in Maass et al. 2005). Similarly, pollination of forest plants, including that of economically useful plants, is a process that goes on within the forest ecosystem, but once the useful products have been valued, one should not value the pollination again.

The point that Lele et al. (2013) make suggests that the ES concept does not do a good job of organizing the boundaries between involved disciplines. It gives no framework for how to connect ecological complexity and dynamics with human wants and needs. Another way to phrase this is that, as an interfield theory, it can be considered underdeveloped.

One problem that has been raised is that the ES cascade draws attention to subsequent steps in the cascade at the expense of fundamental ecological understanding. Much effort in ES research is focused on classifying services and understanding service dynamics in terms of trade-offs, synergies, and bundling (Bennett and Chaplin-Kramer 2016). However, services parse ecosystems according to the needs and wants of humans and are not always dynamically active components of ecosystems (although human actions clearly influence ecosystems), and are certainly not the only components. Jacobs et al. (2013) point out how results from modeling and mapping services are often presented clearly and explicitly, overlooking the underlying uncertainty of inherently complex ecosystem dynamics. La Notte et al. (2017) are explicit in highlighting how challenges arise when applying the cascade framework in practice because flows and assets (i.e., stocks) do not account for the complexity of ecological interactions in a systems ecology perspective. A very general way of analyzing these concerns is that the ES concept, as well as the ES cascade, does not provide a good interfield theory in the sense that it fails to relate stably the ontologies of social science disciplines and ecology. It is difficult to get the boundaries right, in part, perhaps, because of the interactions and interconnections being fickle, messy, and prone to change. Confusion with regard to concepts such as function and service can be taken as testament to this idea.

There are traces of additional ontologically based arguments against ES and the use of conventional economics in ecosystem valuation. Norton (2011) identifies two problems that he sees as central. The first problem he calls the reversibility and substitutability problem, and the second he calls the accounting problem. Both issues have "ontological" components. Concerning reversibility and substitution, Norton (2011:63) writes:

Economists, who engage in analysis of valuation for goods and services 'at the margin', focus on overall welfare, manifest as the average ability of consumers to pay for goods and services they desire. Ecologists, however, are suspicious of marginal analysis of goods 
derived from nature, because they believe ecological systems are complex systems that contain many thresholds and multiple 'regimes of functioning'.

In short, a marginalist economic perspective is problematic to ecologists because it implies that particular services are substitutable with other goods that carry the same value, and that all processes are, in principle, reversible. This misconstrues how ecosystems function, where many important process are, in practice or principle, irreversible, and discontinuity and the presence of dynamical tipping points are perhaps the most salient feature from a human perspective.

The accounting problem concerns the ontology of the values involved. Ecologists and economists deeply disagree not only on "how much value various objects have; they also disagree about what things have value and in what terms those values are to be measured or counted," (Norton 2011:364). We have reasons to return to values more explicitly later, but for now, it is interesting to note that Norton (2011) phrases these differences as explicitly ontological in nature and deploys territorial metaphors that lends themselves well to the terminology of imperialism.

These practical problems pale by comparison with the very great issues associated with what could be referred to as the "ontological" problems that afflict the discourse about environmental values and valuation. Different disciplines develop independent theoretical and conceptual frameworks to explain their respective areas of study, but in the area of environmental valuation, the turf wars and incommensurabilities across disciplinary and theoretical lines have settled into trench warfare, with economists and philosophers as the main antagonists, and with ecologists standing by with crucial insights, but reluctant to enter the values fray for fear of losing their status as "objective, value-neutral, scientists" (Norton 2011:366).

In Norton's (2011) interpretation, the main battle lines are between ecologists and ecological economists on the one side, and conventional marginalist economists on the other. It is quite apparent that ontological concerns, not least ontological concerns with respect to values, have been important among those hesitant about the integrative potential of the ES framework.

\section{Pluralism}

A pervasive critique of the ES framework speaks to the idea that the concept has indeed been overrun by overtly economistic methods and metaphors to the detriment of a broader, more complete understanding of the dynamics of ecosystems. This line of critique is clearly pluralist in nature.

Ecologists understand the complexity of nature using many different frameworks, each of which helps to understand different aspects of natural systems. By focusing on the stock-flow framework, the valuation of ecosystem services and implementation of payments for ES and related projects will have unintended consequences that could have been better foreseen and avoided or adapted by using additional patterns of thinking. The ecosystem service metaphor now blinds us to the complexity of natural systems, the ecological knowledge available to work with that complexity, and the amount of effort, or transactions costs, necessary to engage seriously and effectively with ecosystem management. (Norgaard 2010:1219).
Norgaard (2010) is indicating that the (conventional) economic framing that the ES concept has come to involve is too narrow from an ecological perspective. The ES framework is suppressing the pluralism within the discipline of ecology, a pluralism that is necessary to adequately describe complex systems such as ecosystems.

Norton and Noonan (2007:665) make a similar point but take an interdisciplinary perspective, drawing attention to how conventional economic methodology overrides other social sciences in the ES domain:

What worries us is that the current enthusiasm for
ecosystem service methods (used in tandem with
contingent valuation methods) has locked the rhetoric of
environmental evaluation in a very monistic, utilitarian,
and economic vernacular that leaves little or no room for
other social scientific methods, or for appeal to
philosophical reasons or theological ideals.

For Norton and Noonan (2007), the very adoption of an "economic vernacular" and metaphors are problematic and, in essence, involve a commitment to a certain set of values that are themselves questionable, not only from a scientific perspective, but also from social and ethical perspectives. Silvertown (2015) similarly suggests that the concept has been oversold and that the focus on monetization is preventing adherents of ES from recognizing alternative approaches. Spangenberg and Settele (2010) note that economic valuation of ES is based on an ideal of a pursuit of objectivity as an optimal basis for decision making, regardless of the assumptions and epistemological constraints of the valuation methods, which leads to divergent results depending on the choice of application.

Another interesting observation is that certain ways of construing ES, such as the ES cascade, tend to exert excessive influence on subsequent research, overlooking the plurality of methodologies and perspectives that potentially could inform proceedings. Following the Millennium Ecosystem Assessment in 2005, the main research needs for understanding ES were defined by Carpenter et al. (2006). These needs included the lack of a robust ecological theory linking ecological diversity to ecosystem dynamics and ES, as well as poor or nonexistent indicators and data for many services. Bennett and Chaplin-Kramer (2016) argue that regardless of the boom of ES literature, an understanding of the ecological foundation of ES is still incomplete. Naeem et al. (2015) similarly suggest that the natural scientific basis to the ES approach remains underdeveloped in spite of the intended focus on ecosystem functions. For example, the question remains unanswered of how spatial heterogeneity (uneven distribution of species within one area) affects ecosystem function and the provision of ES (Bennett and Chaplin-Kramer 2016). Even though ecosystem ecologists have provided evidence of ecosystem-level nonlinearities, feedbacks, and thresholds in ecological systems that affect $\mathrm{ES}$ provision, most $\mathrm{ES}$ science is still based on the assumption of linearity according to the ecosystem cascade (Bennett and Chaplin-Kramer 2016). The lack of understanding about the underlying nonlinear ecology has not stopped the rapidly growing field of ES, but has instead lead to cherry-picking ES research that is based on data availability and ease of quantification (McDonough et al. 2017). The enemy of the pluralist, in this case, is methodological convenience. 
Perhaps the lack of plurality in the field of ES is similar to what Norgaard (1989) noted about ecological economics in the late 1980s. A lack of methodological pluralism resulted in analysts repeatedly ignoring how the frameworks that were being relied on precluded the pursuit of certain venues of research.

\section{Value suppression}

Values and valuation are central concerns in ES science and are points of intense and persistent conflict. Above, we have framed the conflict mainly in ontological terms; i.e., there are not only issues associated with connecting economic (and social science) ontologies with ecology but also deep disagreements about values, what they are, and how they are to be understood and construed. Here, the transdisciplinary nature of ES science means that it is not merely about scientific representations, but ultimately about accounting for social and ethical values more broadly in both science and policy. The two issues collapse, as it were. The charge of (economics) imperialism, here, is then that the influence of economics on the ES discussion essentially appropriates a problem that is social and casts it in narrow economic terms. In short, this line of critique concerns how the influence of either conventional economics or, more broadly, economics in general (e.g., Lele et al. 2013) misrepresents how nature is or should be valued. The fears include how economics encompasses certain types of values, how economic influence leads to value monism despite a broadening of disciplinary engagement, and how ES assessments are incapable of capturing a diversity of ecosystem values.

The axiology of what constitutes ES value in valuation has generally been influenced by economic conceptions of value. Goméz-Baggethun et al. (2010) show how the historical development from an economic theory of value building on use value to the current theory of value building on exchange value is crucial for how what types of properties of ecosystems are determined to be included in monetary valuation. An exchange theory of value measures value by determining the ratio in which goods are exchanged based on subjective preferences for those goods. Applying this theory of value to ecosystems, the value of an ecosystem is seen as originating in individuals minds and not in the structures and properties of the ecosystems themselves, i.e., a subjective theory of value. Spangenberg and Settele (2016) point out that because exchange value is measured as marginal utility, by definition it is not possible to value the utility provided from a stock of goods, i.e., a whole ecosystem, but only the flows of goods from that ecosystem. The closest economics can get within its disciplinary boundaries to measuring the value of ecosystems is, as Spangenberg and Settele (2016:103) put it, "in calculating a subjective, instrumental, utilitarian exchange value for something which most probably is unique, representing an inherent value (and sometimes, in addition, an intrinsic value) no market price can buy." Neoclassical economics is also not able to deal with value incommensurability and lexicographic preferences, which are often associated with environmental values (Spash 2000). ${ }^{[3]}$

The idea of subjective value is an important foundation for ecosystem services valuation more broadly, and does not only apply to the narrow orthodox neoclassical economic assumptions of monetary valuation, but also to nonmonetary valuation. From an axiological perspective, subjective values make up only a small part of the values (next to ideal and real or objective values) that can be considered relevant with respect to ES, and within that sphere, only a subset (the instrumental values) can be encompassed by monetary valuation (Spangenberg and Settele 2016).

This underlying axiology of ES also feeds into the philosophical problems associated with the ES concept that have to do with the intersection of economics and ethics. Environmental ethicists, at least since the 1970s (see Brennan and Lo 2016), have often subscribed to metaethical objectivism, arguing that nature is intrinsically valuable in the specific sense that it is valuable independently of a valuer (O'Neill 1992, O'Neill et al. 2008). In this approach, the ES concept appears to be problematic because it fundamentally construes values as subjective, i.e., dependent on some valuing subject (humans). ${ }^{[4]}$ Intrinsic values as objective values cannot be assessed through consulting value judgements of relevant subjects. Nor can they, as it were, be obtained by examining the properties of ecosystems. This particular construal of intrinsic values is not uncontroversial; it has been the subject of much debate in conservation biology (Noss 2007, Justus et al. 2009, White 2013) but nonetheless serves to illustrate some of the difficulties involved in the ES project if the ethical basis is to be taken seriously. Thus, there are issues both with value monism, the charge being that not every relevant value can be fitted within an ES framework, and with the inherent anthropocentrism that follows from relying so heavily on the service metaphor.

Hejnowicz and Rudd (2017) bring up relevant points of criticism of ES valuation that fit well with imperialism as value suppression. Intrinsic values cannot be encompassed by the ES values framework if they are seen as objective values, and nor can ideal values such as equality or justice (Spangenberg and Settele 2016). It has been demonstrated that spiritual and aesthetic values, which can be considered ideal values, have fundamentally different axiological constructions than what can be incorporated into the consequentialist ES framework (Cooper et al. 2016, Stålhammar and Pedersen 2017). Previously, cultural ecosystem services have been acknowledged as partly inappropriate for monetary valuation assessments because of their place-based and incommensurate character (Chan et al. 2012). Instead, social and cultural values are increasingly incorporated by nonmonetary valuation, which is a growing field that draws on diverse social sciences disciplines and includes so-called deliberate valuation and interpretivist approaches (Kelemen et al. 2016, Kenter 2016). As noted by Raymond et al. (2014), some of these methods are similar to the neoclassical monetary valuation approach because they assume that individual values can be quantified and aggregated.

As it currently stands, the broader debate on the value of nature is burdened by a range of different ways of categorizing and theorizing about value that are difficult to disentangle from one another (Hejnowicz and Rudd 2017). A range of disciplines, from ecological economics and ethics to conservation biology and social psychology, all have contributions to make here, but each operate with different categories and value concepts.

It is notable that the ES community has been moved by some of the criticisms. In the launch of its new conceptual framework, the Intergovernmental Platform on Biodiversity and Ecosystem Services (IPBES) has shifted the focus from services to "nature's contribution to people" and from values to "nature's gifts." These changes are hoped to connect better to other (non-Western) knowledge and value systems (Díaz et al. 2015, 2018, Pascual et al. 2017, Tengö et al. 2017). 
In spite of these efforts, there are questions as to what a framework can accomplish with regard to accurately integrating diverse worldviews and nonoverlapping and incommensurable values of nature. The fear is that the ES paradigm is not endlessly expandable and the difficulties with which it is confronted are not methodological, but fundamental. James (2015:347), discussing to what extent the humanities and social sciences can be incorporated in the ES framework, explicitly exemplifies this view:

\section{The ecosystem services framework is therefore totalizing. All manner of different approaches to the cultural value of places, from phenomenology to textual analysis, find themselves reinterpreted in terms of service-provision. And all manner of places get framed as service providers. Beautiful places become suppliers of aesthetic services, sacred places providers of spiritual services. If a place is part of who we are, then that, too, is conceived of as a cultural service which it supplies.}

There are also other ways in which values, broadly construed, come into play in thinking about human-nature relationships. Norton (2011) has pointed to the way in which the metaphors and analogies used in grappling with the relationship between humans and the natural environment are both informed by and, to some extent, perpetuate certain values, and that we therefore should not make these choices lightly. The argument is informed by recent developments in the philosophy of science (e.g., Cartwright 1999, Longino 1996, Dupré 2001, Mitchell 2002, 2008; see also Kellert et al. 2006 for a helpful overview). The idea is that the models, metaphors, and analogies we use to construe reality are inherently partial; this is what makes them at all useful (Mitchell 2008). A map as rich in detail as the landscape it depicts is useless as a map. This partiality of representations means that choices have to be made; certain features are emphasized at the expense of others. What makes a specific representation good or bad depends not merely on, say, structural similarities between model and target system, but also on what the purpose of that representation is, and what is considered to be important about the situation more broadly. Often, epistemic values will fail to inform the inquirer to a sufficient degree. Other values come into play, e.g., social and ethical values, as well as pragmatic considerations (Parker 2014). These choices may or may not be conscious and deliberate, but they do have implications. Different choices of metaphors highlight different aspects of systems while hiding others. The language that the ES discourse is imbued with matters. It is rife with economic metaphors and underlying analogies. This circumstance is apparent, for example, in the socalled ES cascade (Fig. 1). The ES cascade is loosely based on a production chain, a metaphor deployed to explore the intermediate steps linking "final products" (benefits and values) with the underlying ecological structures and processes that give rise to those products. The environment is construed as the "supply side" and the social and economic system as the "demand side." The economic account of value employed by the ES approach has been accused of locking discourse into a "nature as productive factory" theme that limits the creative use of alternative metaphors and accounts of value (Norton 2015).

\section{DISCUSSION AND CONCLUDING REMARKS}

Let us first consider the impacts of ES on the involved disciplines. The modern idea of ES has had an undeniable effect on the disciplines that have engaged with it, in particular economics and ecology, but also a range of other social sciences. In ecology and conservation biology, underdeveloped areas of research have been highlighted, especially indirect use values of ES, leading researchers in these disciplines to now be "more willing to focus on variables that may be of direct relevance to human beings" (Lele et al. 2013:346). This shift in interest, on behalf of ecologists, from focusing on issues such as net primary productivity, nutrient cycling, and patterns of diversity to concerns of more immediate pertinence to humans has also led to a change in the interdisciplinary landscape. Ecologists have increasingly moved to collaborate with economists, and economists have not been untouched by the encounter. Lele et al. (2013:345) suggest that some of the appeal of the ecosystem service concept flows from how it has gotten otherwise economics-averse ecologists to contribute to economic analysis and assessment. At the same time, important concessions have been made by (some) neoclassical economists, who have come to embrace a strong concept of sustainability.

Spangenberg and Settele (2016) suggest that much of the policy impact of the ES concept is still primarily due to its use as an illustrative metaphor, not as a quantitative framework.

We have shown that, at some level, there seem to be contradictory lines of critique that have been directed at the ES concept. It has been suggested that the concept is too vague and ambiguous to establish a connection on which genuine interdisciplinary inquiry may be built. A minimal conclusion here is that studying ES on its own need not involve any deeper integrative efforts. This fact does not necessarily exclude secondary effects that using a similar label across disciplines may bring. Neither does it say anything definitive about what is forthcoming, at least not on its own. In apparent contradiction to the idea that the ES concept is too barren and vacuous to "maintain identity across sites" (Star and Griesemer 1989), other common charges suggest that the concept is overburdened with content. A commitment to ES leads, maybe inevitably, to a particular, narrow, and exclusive understanding of how human societies relate to the natural environment. However, these two ideas are not necessarily contradictory. An empty concept can be filled with particular meanings and is thus subject to precisely the kind of hostile takeover of which scientific anti-imperialists are wary.

Suppose we turn the question around. In what way does economics inform ecology? As pointed out by Lele et al. (2013), the broad influence of the ES concept has moved ecologists to take on a more anthropocentric perspective. The study by Baumgardner et al. (2012), which, from a strictly ecological perspective, is looking at periurban forests and their effects on air quality, might be an illustration of this development. It is more questionable if economics has anything deeper to say about ecology as such. ${ }^{[5]}$ Taking this stance, it would appear that ecologists are the more likely candidates to be imperialists, albeit not perhaps in a normatively negative sense, depending on one's perspective.

So, how are we to think of the imperialism metaphor here? The struggle is between economics, ecology, and a few intermediary positions, as well as the social sciences as a whole. Recent developments suggest an increasing awareness that something has been overlooked with regard to the social sciences and humanities (Vadrot et al. 2018a,b) such as the significance of meanings, 
aspirations, and desires with regard to values of biodiversity (Jetzkowitz et al. 2018).

A central concern is then: On who's or what terms? What disciplines should be involved in or contribute to a science of ES, and how should one appropriately arrange those disciplines with respect to one another? What are the constraints on involvement from these new (social science) actors in the debate? Answering these questions depends on whether we perceive the field as delimited by the ES concept itself, and thus subject to whatever constraints are associated with that concept, or by some set of more broadly formulated problems and aims. Recent developments such as IPBES shift in terminology suggest that an awareness is growing within this field that the theoretical framework needs to make more room for interdisciplinarity. The question of on whose terms interdisciplinary efforts operate is not straightforward because the fact that the imperialized are actively taking part in the process needs not imply that the infringement is scientifically well advised (Mäki 2009). The pressure to conform to economics as a discipline among other social sciences is considerable and probably should not be seen as entirely voluntary (Mäki 2009). As acknowledged by Spash and Aslaksen (2015), pragmatically driven ecologists might even be aware that the numbers they are helping to create through ES assessments lack scientific credibility and meaning, but that their main concern is their participation and new voice in the political arena, which provides enough justification.

These concerns gain momentum from the successive transformation of the ES framework more broadly from an illustrative metaphor to a decision-making paradigm (Norgaard 2010). Ultimately, a conclusion on the general state of discourse might be that both the descriptive question of what role economics has in ES theorizing and discourse, and the normative question that regards what role it should have, remain unsettled and important points of contention. It is quite clear that, whatever its benefits are, the service metaphor itself (like any metaphor) highlights certain aspects of human-nature relationships at the expense of others. Viewed that way, the notion that this basic metaphor could somehow be indefinitely expanded to include every relevant aspect of this relationship seems fundamentally flawed. That is just not how metaphors or representations work (Mitchell 2008).

Recent and ongoing developments suggest that increased attention should be given to how the ES field deals with the theoretical complexities of achieving interdisciplinarity in integrating disciplines for valuation and assessments. These developments include the idea of "integrated valuation," which strives to integrate ecological, economic, and social values of ES (Jacobs et al. 2018), as well as the idea of "connecting diverse knowledge systems" of ES through combining indigenous and scientific knowledge (Tengö et al. 2014, 2017). It is critical to scrutinize the constraints involved in determining the integration and translation (i.e., Tengö et al. 2017) of knowledge.

In future work, quantitative documentation would be informative, at least as a compelling supplement to a qualitative analysis of the literature. Of particular interest should be how the ES framework and its presumptive successors develop to include further social science disciplines and on what premises that involvement is conditioned.
To conclude, the picture that emerges is admittedly mixed, and one should take care to avoid categorical statements or predictions. Scientific concepts are malleable entities and may change in surprising ways over time, and even failed metaphors may serve to highlight important aspects of what is studied and to provoke interesting questions. Perhaps an argument could be mounted that the contribution of the ES concept is not primarily in what it manages to capture, but rather how it has provoked debate about all that it appears to omit. There is now a rich, wide ranging discussion on how to think properly of human-nature relationships. In this, the ES concept has clearly been a catalyst, even with all its presumptive flaws.

\footnotetext{
${ }^{[1]}$ We thank one of the anonymous reviewers, who encouraged us to take a more ambitious approach than we had initially intended.

${ }^{[2]}$ Precisely how to cash out this requirement is not straightforward (see Kuorikoski and Lehtinen 2009).

${ }^{[3]}$ Lexicographic preferences, roughly speaking, have to do with how people sometimes tend to value different types of goods according to different scales. For a starving person, for instance, no amount of screwdrivers could replace a meal. See Spash (2000) for a detailed discussion.

${ }^{[4]}$ Notably, it is not necessarily the case that ES are committed to instrumental values. A metaethical subjectivist can coherently think of certain things as valued for their own sake, even if those values are dependent on the presence of a valuing subject (O'Neill 1992).

${ }^{[5]}$ MacLeod and Nagatsu (2016) provide an interesting potential counterexample in which the economic component in integrated economic-ecological models was used to find weaknesses in the ecological component.
}

Responses to this article can be read online at: http://www.ecologyandsociety.org/issues/responses. php/10520

\section{Acknowledgments:}

We thank two anonymous reviewers for some very helpful and constructive comments on an earlier version of this paper. We also thank our dear colleagues at LUCSUS for giving useful and interesting input at seminars. This paper was written within the LUCID project funded by The Swedish Research Council Formas (Linneus Centre LUCID; grant 259-2008-1718).

\section{LITERATURE CITED}

Abson, D. J., H. von Wehrden, S. Baumgärtner, J. Fischer, J. Hanspach, W. Härdtle, H. Heinrichs, A. M. Klein, D. J. Lang, P. Martens, and D Walmsley. 2014. Ecosystem services as a boundary object for sustainability. Ecological Economics 103:29-37. http://dx.doi.org/10.1016/j.ecolecon.2014.04.012

Apostel, L., G. Berger, A. Briggs, and G. Michaud, editors. 1972. Interdisciplinarity: problems of teaching and research in universities. Centre for Educational Reearch and Innovation, 
Organisation for Economic Co-operation and Development, Paris.

Bammer, G. 2013. Disciplining interdisciplinarity: integration and implementation sciences for researching complex real-world problems. ANU Press, Canberra, Australia. http://dx.doi. org/10.22459/DI.01.2013

Baumgardner, D., S. Varela, F. J. Escobedo, A. Chacalo, and C. Ochoa. 2012. The role of a peri-urban forest on air quality improvement in the Mexico City megalopolis. Environmental Pollution 163:174-183. http://dx.doi.org/10.1016/j.envpol.2011.12.016

Bechtel, W. 1986. The nature of scientific integration. Pages 1-51 in W. Bechtel, editor. Integrating scientific disciplines. Springer, Dordrecht, The Netherlands. http://dx.doi.org/10.1007/978-94-$\underline{010-9435-1 \quad 1}$

Bennett, E. M., and R. Chaplin-Kramer. 2016. Science for the sustainable use of ecosystem services. F1000Research 20165 (F1000 Faculty Rev):2622. https://doi.org/10.12688/f1000research.9470.1

Braat, L. C. 2018. Five reasons why the Science publication "Assessing nature's contributions to people" (Diaz et al. 2018) would not have been accepted in Ecosystem Services. Ecosystem Services 30(A):A1-A2. https://doi.org/10.1016/j.ecoser.2018.02.002

Braat, L. C., and R. de Groot. 2012. The ecosystem services agenda: bridging the worlds of natural science and economics, conservation and development, and public and private policy. Ecosystem Services 1(1):4-15. http://dx.doi.org/10.1016/j. ecoser.2012.07.011

Brennan, A., and Y.-S. Lo. 2016. Environmental ethics. In E. N. Zalta, editor. The Stanford encyclopedia of philosophy. Winter 2016 edition. Stanford University, Stanford, California, USA. [online] URL: https://plato.stanford.edu/archives/win2016/entries/ ethics-environmental/

Burkhard, B., I. Petrosillo, and R. Costanza. 2010. Ecosystem services - bridging ecology, economy and social sciences. Ecological Complexity 7(3):257-259. http://dx.doi.org/10.1016/j. ecocom.2010.07.001

Carpenter, S. R., R. DeFries, T. Dietz, H. A. Mooney, S. Polasky, W. V. Reid, and R. J. Scholes. 2006. Millennium Ecosystem Assessment: research needs. Science 314:257-258. http://dx.doi. org/10.1126/science. 1131946

Cartwright, N. 1999. The dappled world: a study of the boundaries of science. Cambridge University Press, Cambridge, UK. http:// dx.doi.org/10.1017/CBO9781139167093

Cat, J. 2017. The unity of science. In E. N. Zalta, editor. The Stanford encyclopedia of philosophy. Fall 2017 Edition. Stanford University, Stanford, California, USA. [online] URL: https:// plato.stanford.edu/archives/fall2017/entries/scientific-unity/

Chan, K. M. A., A. D. Guerry, P. Balvanera, S. Klain, T. Satterfield, X. Basurto, A. Bostrom, R. Chuenpagdee, R. Gould, B. S. Halpern, N. Hannahs, J. Levine, B. Norton, M. Ruckelshaus, R. Russel, J. Tam, and U. Woodside. 2012. Where are cultural and social in ecosystem services? A framework for constructive engagement. Bioscience 62(8):744-756. http://dx.doi.org/10.1525/ bio.2012.62.8.7
Chaudhary, S., A. McGregor, D. Houston, and N. Chettri. 2015. The evolution of ecosystem services: a time series and discoursecentered analysis. Environmental Science and Policy 54:25-34. http://dx.doi.org/10.1016/j.envsci.2015.04.025

Clarke, S., and A. Walsh. 2009. Scientific imperialism and the proper relations between the sciences. International Studies in the Philosophy of Science 23(2):195-207. http://dx.doi. org/10.1080/02698590903007170

Cooper, N., E. Brady, H. Steen, and R. Bryce. 2016. Aesthetic and spiritual values of ecosystems: recognising the ontological and axiological plurality of cultural ecosystem 'service'. Ecosystem Services 21(B):218-229. http://dx.doi.org/10.1016/j.ecoser.2016.07.014

Costanza, R., R. d'Arge, R. de Groot, S. Farber, M. Grasso, B. Hannon, K. Limburg, S. Naeem, R. V. O’Neill, J. Paruelo, R. G. Raskin, P. Sutton, and M. van den Belt. 1997. The value of the world's ecosystem services and natural capital. Nature 387:253-260. http://dx.doi.org/10.1038/387253a0

Costanza, R., R. de Groot, L. Braat, I. Kubiszewski, L. Fioramonti, P. Sutton, S. Farber, and M. Grasso. 2017. Twenty years of ecosystem services: How far have we come and how far do we still need to go? Ecosystem Services 28(A):1-16. http://dx. doi.org/10.1016/j.ecoser.2017.09.008

Daily, G. C., editor. 1997. Nature's services: societal dependence on natural ecosystems. Island Press, Washington, D.C., USA.

Darden, L. 1991. Theory change in science: strategies from Mendelian genetics. Oxford University Press, Oxford, UK.

Darden, L., and N. Maull. 1977. Interfield theories. Philosophy of Science 44(1):43-64. http://dx.doi.org/10.1086/288723

Díaz, S., S. Demissew, J. Carabias, C. Joly, M. Lonsdale, N. Ash, A. Larigauderie, J. R. Adhikari, S. Arico, A. Báldi, A. Bartuska, I. A. Baste, A. Bilgin, E. Brondizio, K. M. A. Chan, V. E. Figueroa, A. Duraiappah, M. Fischer, R. Hill, T. Koetz, P. Leadley, P. Lyver, G. M. Mace, B. Martin-Lopez, M. Okumura, D. Pacheco, U. Pascual, E. S. Pérez, B. Reyers, E. Roth, O. Saito, R. J. Scholes, N. Sharma, H. Tallis, R. Thaman, R. Watson, T. Yahara, Z. A. Hamid, C. Akosim, Y. Al-Hafedh, R. Allahverdiyev, E. Amankwah, S. T. Asah, Z. Asfaw, G. Bartus, L. A. Brooks, J. Caillaux, G. Dalle, D. Darnaedi, A. Driver, G. Erpul, P. EscobarEyzaguirre, P. Failler, A. M. M. Fouda, B. Fu, H. Gundimeda, S. Hashimoto, F. Homer, S. Lavorel, G. Lichtenstein, W. A. Mala, W. Mandivenyi, P. Matczak, C. Mbizvo, M. Mehrdadi, J. P. Metzger, J. B. Mikissa, H. Moller, H. A. Mooney, P. Mumby, H. Nagendra, C. Nesshover, A. A. Oteng-Yeboah, G. Pataki, M. Roué, J. Rubis, M. Schultz, P. Smith, R. Sumaila, K. Takeuchi, S. Thomas, M. Verma, Y. Yeo-Chang, and D. Zlatanova. 2015. The IPBES conceptual framework - connecting nature and people. Current Opinion in Environmental Sustainability 14:1-16. https:// doi.org/10.1016/j.cosust.2014.11.002

Díaz, S., U. Pascual, M. Stenseke, B. Martín-López, R. T. Watson, Z. Molnár, R. Hill, K. M. A. Chan, I. A. Baste, K. A. Brauman, S. Polasky, A. Church, M. Lonsdale, A. Larigauderie, P. W. Leadley, A. P. E. van Oudenhoven, F. van der Plaat, M. Schröter, S. Lavorel, Y. Aumeeruddy-Thomas, E. Bukvareva, K. Davies, S. Demissew, G. Erpul, P. Failler, C. A. Guerra, C. L. Hewitt, H. Keune, S. Lindley, and Y. Shirayama. 2018. Assessing nature's 
contributions to people. Science 359:270-272. http://dx.doi. org/10.1126/science.aap8826

Donovan, G. H., and D. T. Butry. 2011. The effect of urban trees on the rental price of single-family homes in Portland, Oregon. Urban Forestry and Urban Greening 10(3):163-168. http://dx.doi. org/10.1016/j.ufug.2011.05.007

Dupré, J. 1996. Against scientific imperialism. Pages 374-381 in M. Forbes, D. Hull, and R. M. Burian, editors. PSA 1994: proceedings of the 1994 biennial meeting of the Philosophy of Science Association. Volume 2. Philosophy of Science Association, East Lansing, Michigan, USA.

Dupré, J. 2001. Human nature and the limits of science. Clarendon Press, Oxford, UK. http://dx.doi.org/10.1093/0199248060.001.0001

Ehrlich, P., and A. Ehrlich. 1981. Extinction: the causes and consequences of the disappearance of species. Random House, New York, New York, USA.

Ehrlich, P. R., and H. A. Mooney. 1983. Extinction, substitution, and ecosystem services. Bioscience 33(4):248-254. http://dx.doi. org/10.2307/1309037

Fisher, B., R. K. Turner, and P. Morling. 2009. Defining and classifying ecosystem services for decision making. Ecological Economics 68(3):643-653. http://dx.doi.org/10.1016/j. ecolecon.2008.09.014

Fumagalli, R. 2018. Who is afraid of scientific imperialism? Synthese 195(9):4125-4146. https://doi.org/10.1007/s11229-017-1411-2

Gómez-Baggethun, E., R. de Groot, P. L. Lomas, and C. Montes. 2010. The history of ecosystem services in economic theory and practice: from early notions to markets and payment schemes. Ecological Economics 69(6):1209-1218. http://dx.doi.org/10.1016/ j.ecolecon.2009.11.007

Haines-Young, R., and M. Potschin. 2010. The links between biodiversity, ecosystem services and human well-being. Pages 110-139 in D. G. Raffaelli and C. L. J. Frid, editors. Ecosystem ecology: anew synthesis. Cambridge University Press, Cambridge, UK. http://dx.doi.org/10.1017/CBO9780511750458.007

Hejnowicz, A. P., and M. A. Rudd. 2017. The value landscape in ecosystem services: value, value wherefore art thou value? Sustainability 9(5):850. http://dx.doi.org/10.3390/su9050850

Jacobs, S., H. Keune, D. Vrebos, O. Beauchard, F. Villa, and P. Meire. 2013. Ecosystem service assessments: science or pragmatism? Pages 157-165 in S. Jacobs, N. Dendoncker, and H. Keune, editors. Ecosystem services: global issues, local practices. Elsevier, Amsterdam, The Netherlands. https://doi.org/10.1016/ B978-0-12-419964-4.00014-7

Jacobs, S., B. Martín-López, D. N. Barton, R. Dunford, P. A. Harrison, E. Kelemen, H. Saarikoski, M. Termansen, M. GarcíaLlorente, E. Gómez-Baggethun, L. Kopperoinen, S. Luque, I. Palomo, J. A. Priess, G. M. Rusch, P. Tenerelli, F. Turkelboom, R. Demeyer, J. Hauck, H. Keune, and R. Smith. 2018. The means determine the end - pursuing integrated valuation in practice. Ecosystem Services 29(C):515-528. https://doi.org/10.1016/j. ecoser.2017.07.011
James, S. P. 2015. Cultural ecosystem services: a critical assessment. Ethics, Policy and Environment 18(3):338-350. http:// dx.doi.org/10.1080/21550085.2015.1111616

Jax, K. 2016. Ecosystem functions: a critical perspective. Pages 42-44 in M. Potschin, R. Haines-Young, R. Fish, and R. K. Turner, editors. Routledge handbook of ecosystem services. Routledge, London, UK.

Jetzkowitz, J., C. S. A. van Koppen, R. Lidskog, K. Ott, L. VogetKleschin, and C. M. L. Wong. 2018. The significance of meaning. Why IPBES needs the social sciences and humanities. Innovation: The European Journal of Social Science Research 31:S38-S60. https://doi.org/10.1080/13511610.2017.1348933

Justus, J., M. Colyvan, H. Regan, and L. Maguire. 2009. Buying into conservation: intrinsic versus instrumental value. Trends in Ecology and Evolution 24(4):187-191. http://dx.doi.org/10.1016/j. tree.2008.11.011

Kelemen, E., M. García-Llorente, G. Pataki, B. Martín-López, and E. Gómez-Baggethun. 2016. Non-monetary techniques for the valuation of ecosystem services. In M. Potschin-Young and K. Jax, editors. OpenNESS ecosystem services reference book. Operationalisation of natural capital and ecosystem services, Finnish Environment Institute, Helsinki, Finland. [online] URL: http://www.openness-project.eu/library/reference-book/sp-non-monetaryvaluation

Kellert, S. H., H. E. Longino, and C. K. Waters. 2006. Introduction: the pluralist stance. Pages vii-xxix in S. H. Kellert, H. E. Longino, and C. K. Waters, editors. Scientific pluralism. University of Minnesota Press, Minneapolis, Minnesota, USA.

Kenter, J. O. 2016. Deliberative and non-monetary valuation. Pages 271-288 in M. Potschin, R. Haines-Young, R. Fish, and R. $\mathrm{K}$. Turner, editors. Routledge handbook of ecosystem services. Routledge, London, UK.

Klein, J. T. 1990. Interdisciplinarity: history, theory, and practice. Wayne State University Press, Detroit, Michigan, USA.

Klein, J. T. 2012. Research integration: a comparative knowledge base. Pages 283-298 in A. F. Repko, W. H. Newell, and R. Szostak, editors. Case studies in interdisciplinary research. Sage, Thousand Oaks, California, USA.

Kuhn, T. 1970. The structure of scientific revolutions. Second edition. University of Chicago Press, Chicago, Illinois, USA.

Kuorikoski, J., and A. Lehtinen. 2009. Economics imperialism and solution concepts in political science. Philosophy of the Social Sciences Philosophy of the Social Sciences 40(3):347-374. http:// dx.doi.org/10.1177/0048393109341452

La Notte, A., D. D’Amato, H. Mäkinen, M. L. Paracchini, C. Liquete, B. Egoh, D. Geneletti, and N. D. Crossman. 2017. Ecosystem services classification: a systems ecology perspective of the cascade framework. Ecological Indicators 74:392-402. http://dx.doi.org/10.1016/j.ecolind.2016.11.030

Lele, S., O. Springate-Baginski, R. Lakerveld, D. Deb, and P. Dash. 2013. Ecosystem services: origins, contributions, pitfalls, and alternatives. Conservation and Society 11(4):343-358. http:// dx.doi.org/10.4103/0972-4923.125752 
Longino, H. 1996. Cognitive and non-cognitive values in science. Pages 39-58 in L. H. Nelson and J. Nelson, editors. Feminism, science, and the philosophy of science. Kluwer, Dordrecht, The Netherlands.

Maass, J., P. Balvanera, A. Castillo, G. C. Daily, H. A. Mooney, P. Ehrlich, M. Quesada, A. Miranda, V. J. Jaramillo, F. GarcíaOliva, A. Martínez-Yrizar, H. Cotler, J. López-Blanco, A. PérezJiménez, A. Búrquez, C. Tinoco, G. Ceballos, L. Barraza, R. Ayala, and J. Sarukhán. 2005. Ecosystem services of tropical dry forests: insights from long-term ecological and social research on the Pacific Coast of Mexico. Ecology and Society 10(1):17. [online] URL: http://www.ecologyandsociety.org/vol10/iss1/art17/

MacLeod, M., and M. Nagatsu. 2016. Model coupling in resource economics: conditions for effective interdisciplinary collaboration. Philosophy of Science 83(3):412-433. http://dx.doi.org/10.1086/685745

Mäki, U. 2009. Economics imperialism: concept and constraints. Philosophy of the Social Sciences 39(3):351-380. http://dx.doi. org/10.1177/0048393108319023

Mäki, U. 2013. Scientific imperialism: difficulties in definition, identification, and assessment. International Studies in the Philosophy of Science 27(3):325-339. http://dx.doi. org/10.1080/02698595.2013.825496

Maull, N. L. 1977. Unifying science without reduction. Studies in History and Philosophy of Science: Part A 8(2):143-162. http:// dx.doi.org/10.1016/0039-3681(77)90012-7

McDonough, K., S. Hutchinson, T. Moore, and J. M. S. Hutchinson. 2017. Analysis of publication trends in ecosystem services research. Ecosystem Services 25:82-88. http://dx.doi. org/10.1016/j.ecoser.2017.03.022

Midgley, M. 1984. Reductivism, fatalism and sociobiology. Journal of Applied Philosophy 1(1):107-114. http://dx.doi. org/10.1111/j.1468-5930.1984.tb00190.x

Millenium Ecosystem Assessment. 2005. Ecosystems and human well-being: synthesis. Island Press, Washington, D.C., USA. [online] URL: https://www.millenniumassessment.org/documents/ document.356.aspx.pdf

Mitchell, S. 2002. Integrative pluralism. Biology and Philosophy 17(1):55-70.

Mitchell, S. D. 2009. Unsimple truths: science, complexity, and policy. University Of Chicago Press, Chicago, Illinois, USA.

Mooney, H. A., and P. R. Ehrlich. 1997. Ecosystem services: a fragmentary history. Pages 11-19 in G. C. Daily, editor. Nature's services: societal dependence on natural ecosystems. Island Press, Washington, D.C., USA.

Naeem, S., J. C. Ingram, A. Varga, T. Agardy, P. Barten, G. Bennett, E. Bloomgarden, L. L. Bremer, P. Burkill, M. Cattau, C. Ching, M. Colby, D. C. Cook, R. Costanza, F. DeClerck, C. Freund, T. Gartner, R. Goldman-Benner, J. Gunderson, D. Jarrett, A. P. Kinzig, A. Kiss, A. Koontz, P. Kumar, J. R. Lasky, M. Masozera, D. Meyers, F. Milano, L. Naughton-Treves, E. Nichols, L. Olander, P. Olmsted, E. Perge, C. Perrings, S. Polasky, J. Potent, C. Prager, F. Quétier, K. Redford, K. Saterson, G. Thoumi, M. T. Vargas, S. Vickerman, W. Weisser, D. Wilkie, and S. Wunder. 2015. Get the science right when paying for nature's services. Science 347:1206-1207. http://dx.doi.org/10.1126/ science.aaa 1403

Nahlik, A. M., M. E. Kentula, M. S. Fennessy, and D. H. Landers. 2012. Where is the consensus? A proposed foundation for moving ecosystem service concepts into practice. Ecological Economics 77:27-35. http://dx.doi.org/10.1016/j.ecolecon.2012.01.001

Norgaard, R. B. 1989. The case for methodological pluralism. Ecological Economics 1(1):37-57. https://doi.org/10.1016/0921-8009 (89)90023-2

Norgaard, R. B. 2010. Ecosystem services: from eye-opening metaphor to complexity blinder. Ecological Economics 69 (6):1219-1227. http://dx.doi.org/10.1016/j.ecolecon.2009.11.009

Norton, B. G. 2011. Modeling sustainability in economics and ecology. Pages 363-398 in K. deLaplante, B. Brown, and K. A. Peacock, editors. Philosophy of ecology. Elsevier, Oxford, UK. http://dx.doi.org/10.1016/B978-0-444-51673-2.50014-5

Norton, B. G. 2015. Sustainable values, sustainable change: a guide to environmental decision making. University of Chicago Press, Chicago, Illinois, USA.

Norton, B. G., and D. Noonan. 2007. Ecology and valuation: big changes needed. Ecological Economics 63(4):664-675. http://dx. doi.org/10.1016/j.ecolecon.2007.02.013

Noss, R. F. 2007. Values are a good thing in conservation biology. Conservation Biology 21(1):18-20. http://dx.doi.org/10.1111/ j.1523-1739.2006.00637.x

O'Neill, J. 1992. The varieties of intrinsic value. The Monist 75 (2):119-137. http://dx.doi.org/10.5840/monist19927527

O’Neill, J., A. Holland, and A. Light. 2008. Environmental values. Routledge, London, UK. http://dx.doi.org/10.4324/9780203495452

O'Rourke, M., S. Crowley, and C. Gonnerman. 2016. On the nature of cross-disciplinary integration: a philosophical framework. Studies in History and Philosophy of Science Part C: Biological and Biomedical Sciences 56:62-70. http://dx.doi. org/10.1016/j.shpsc.2015.10.003

Parker, W. S. 2014. Values and uncertainties in climate prediction, revisited. Studies in History and Philosophy of Science 46 (C):24-30. http://doi.org/10.1016/j.shpsa.2013.11.003

Pascual, U., P. Balvanera, S. Díaz, G. Pataki, E. Roth, M. Stenseke, R. T. Watson, E. Başak Dessane, M. Islar, E. Kelemen, V. Maris, M. Quaas, S. M. Subramanian, H. Wittmer, A. Adlan, S. Ahn, Y. S. Al-Hafedh, E. Amankwah, S. T. Asah, P. Berry, A. Bilgin, S. J. Breslow, C. Bullock, D. Cáceres, H. Daly-Hassen, E. Figueroa, C. D. Golden, E. Gómez-Baggethun, D. GonzálezJiménez, J. Houdet, H. Keune, R. Kumar, K. Ma, P. H. May, A. Mead, P. O'Farrell, R. Pandit, W. Pengue, R. Pichis-Madruga, F. Popa, S. Preston, D. Pacheco-Balanza, H. Saarikoski, B. B. Strassburg, M. van den Belt, M. Verma, F. Wickson, and N. Yagi. 2017. Valuing nature's contributions to people: the IPBES approach. Current Opinion in Environmental Sustainability 26-27:7-16. http://dx.doi.org/10.1016/j.cosust.2016.12.006

Persson, J., H. Thorén, and L. Olsson. 2018. The interdisciplinary decision problem: Popperian optimism and Kuhnian pessimism in forestry. Ecology and Society 23(3):40. https://doi.org/10.5751/ ES-10401-230340 
Potschin-Young, M., R. Haines-Young, C. Görg, U. Heink, K. Jax, and C. Schleyer. 2018. Understanding the role of conceptual frameworks: reading the ecosystem service cascade. Ecosystem Services 29(C):428-440. http://dx.doi.org/10.1016/j.ecoser.2017.05.015

Raymond, C. M., J. O. Kenter, T. Plieninger, N. J. Turner, and K. A. Alexander. 2014. Comparing instrumental and deliberate paradigms underpinning the assessment of social values for cultural ecosystem services. Ecological Econonomics 107:145-156. http://dx.doi.org/10.1016/j.ecolecon.2014.07.033

Reyers, B., D. J. Roux, and P. J. O'Farrell. 2010. Can ecosystem services lead ecology on a transdisciplinary pathway? Environmental Conservation 37(4):501-511. http://doi.org/10.1017/ $\underline{\mathrm{S} 0376892910000846}$

Rolin, K. 2015. Economics imperialism and epistemic cosmopolitanism. International Studies in the Philosophy of Science 29(4):413-429. http://dx.doi.org/10.1080/02698595.2015.1195145

Schröter, M., E. H. van der Zanden, A. P. E. van Oudenhoven, R. P. Remme, H. M. Serna-Chavez, R. S. de Groot, and P. Opdam. 2014. Ecosystem services as a contested concept: a synthesis of critique and counter-arguments. Conservation Letters 7 (6):514-523. http://dx.doi.org/10.1111/conl.12091

Silvertown, J. 2015. Have ecosystem services been oversold? Trends in Ecology and Evolution 30(11):641-648. https://doi. org/10.1016/j.tree.2015.08.007

Spangenberg, J. H., and J. Settele. 2010. Precisely incorrect? Monetising the value of ecosystem services. Ecological Complexity 7(3):327-337. http://dx.doi.org/10.1016/j.ecocom.2010.04.007

Spangenberg, J. H., and J. Settele. 2016. Value pluralism and economic valuation - defendable if well done. Ecosystem Services 18:100-109. http://dx.doi.org/10.1016/j.ecoser.2016.02.008

Spash, C. L. 2000. Ecosystems, contingent valuation and ethics: the case of wetland re-creation. Ecological Economics 34 (2):195-215. http://dx.doi.org/10.1016/S0921-8009(00)00158-0

Spash, C. L., and I. Aslaksen. 2015. Re-establishing an ecological discourse in the policy debate over how to value ecosystems and biodiversity. Journal of Environmental Management 159:245-253. http://dx.doi.org/10.1016/j.jenvman.2015.04.049

Stålhammar, S., and E. Pedersen. 2017. Recreational cultural ecosystem services: How do people describe the value? Ecosystem Services 26(A):1-9. https://doi.org/10.1016/j.ecoser.2017.05.010

Star, S. L. 2010. This is not a boundary object: reflections on the origin of a concept. Science, Technology, and Human Values 35 (5):601-617. https://doi.org/10.1177/0162243910377624

Star, S. L., and J. R. Griesemer. 1989. Institutional ecology, 'translations' and boundary objects: amateurs and professionals in Berkeley's Museum of Vertebrate Zoology, 1907-39. Social Studies of Science 19(3):387-420. https://doi.org/10.1177/030631289019003001

Tengö, M., E. S. Brondizio, T. Elmqvist, P. Malmer, and M. Spierenburg. 2014. Connecting diverse knowledge systems for enhanced ecosystem governance: the multiple evidence base approach. Ambio 43(5):579-591. https://doi.org/10.1007/

$\underline{\mathrm{s} 13280-014-0501-3}$
Tengö, M., R. Hill, P. Malmer, C. M. Raymond, M. Spierenburg, F. Danielsen, T. Elmqvist, and C. Folke. 2017. Weaving knowledge systems in IPBES, CBD and beyond-lessons learned for sustainability. Current Opinion in Environmental Sustainability 26-27:17-25. http://dx.doi.org/10.1016/j.cosust.2016.12.005

Thorén, H. 2015. History and philosophy of science as an interdisciplinary field of problem transfers. Pages 147-159 in S. Wagenknecht, N. J. Nersessian, and H. Andersen, editors. Empirical philosophy of science: introducing qualitative methods into philosophy of science. Springer, Cham, Switzerland. http:// dx.doi.org/10.1007/978-3-319-18600-9 8

Thorén, H., and J. Persson. 2013. The philosophy of interdisciplinarity: sustainability science and problem-feeding. Journal of General Philosophy of Science 44(2):337-355. http://dx. doi.org/10.1007/s10838-013-9233-5

Vadrot, A. B. M., M. Akhtar-Schuster, and R. T. Watson. $2018 a$. The social sciences and the humanities in the intergovernmental science-policy platform on biodiversity and ecosystem services (IPBES). Innovation: The European Journal of Social Science Research 31(S1):S1-S9. https://doi.org/10.1080/13511610.2018.1424622

Vadrot, A. B. M., A. Rankovic, R. Lapeyre, P.-M. Aubert, and Y. Laurans. 2018b. Why are social sciences and humanities needed in the works of IPBES? A systematic review of the literature. Innovation: The European Journal of Social Science Research 31 (S1):S78-S100. https://doi.org/10.1080/13511610.2018.1443799

Westman, W. E. 1977. How much are nature's services worth? Science 197:960-964. http://dx.doi.org/10.1126/science.197.4307.960

White, P. S. 2013. Derivation of the extrinsic values of biological diversity from its intrinsic value and of both from the first principles of evolution. Conservation Biology 27(6):1279-1285. http://dx.doi.org/10.1111/cobi.12125 